\title{
CHAPTER 19 \\ TRACING COASTAL SEDIMENT MOVEMENT BY NATURALLY RADIOACTIVE MINERALS
}

\author{
A. M. Kamel and J. W. Johnson \\ College of Engineering \\ University of California \\ Berkeley
}

\section{INTRODUCTION}

The process by which sediments are moved along the shore is known as littoral drift and it includes beach drifting and longshore drift (Johnson, 1919). Coarse material is moved along a foreshore in zig-zag paths under the influence of swash and backwash of the waves. The process of longshore drift is due to longshore currents set up within the breaker zone by breaking waves approaching the shoreline at an angle. Although the waves tend to become parallel to the coast as a result of refraction, they usually break at a slight angle to the shore with the result that a littoral current is induced and is effective in moving a mass of water (and the sediment placed in suspension by the breaking waves) slowly along the coast. It is this current combined with the agitating action of the breaking waves, that is the primary factor in causing movement of sand along a coastline. It is believed that the largest percentage of the littoral transport occurs shoreward of the breaking point of the waves.

\section{METHODS OF TRACING THE SOURCE AND DIRECTION OF LITTORAL DRIFT}

Knowledge of sand sources and direction of littoral drift along a coast are of prime importance in beach erosion studies. These factors may be determined broadly by several distinct methods of approach, some of which are necessarily complementary to each other. These include:

(1) The use of standard hydrographic methods of mapping the sea bed and shoreline, aerial surveys, wave data, and refraction diagram analyses, current measurements, sampling of suspended load and bed load sediments, etc.

(2) The use of natural tracers such as heavy mineral fractions or shell inclusions in sediment samples, in relation to their source areas.

(3) The use of radioisotopes as tracers for labeling sediment 


\section{TRACING COASTAL SEDIMENT MOVEMENT BY NATURALLY RADIOACTIVE MINERALS}

samples, elther by incorporation of the activated material in artificial sediment, or by chemical or physical adhesion as a radioactive film on the particles of the real sediment, or by embedment within the particles (in the case of pebbles).

(4) The use of luminophors as tracers for labeling sediment samples, either by incorporation of the fluorescent material in artificial sediment or shingle, or by adhesion as a luminescent film on particles of natural sediment.

(5) The use of hydraulic models with movable beds of artificial materials to simulate prototype sediment processes.

In this study thorium ( $\mathrm{Th}^{232}, 0.238 \mathrm{mev}$ ) was used as a natural tracer to determine the direction of littoral drift along the California coast. This radioactive thorium is added naturally at discrete places along the coast where rivers flowing through thorium rich granite outcrops reach the coast or where the thorium rich granite itself outcrops at the sea coast.

\section{SOURCE OF RADIOACTIVITY}

For a natural rock practically all the gamma radiation comes from three sources, namely: $\mathrm{K}^{40}, \mathrm{U}^{238}$ series, and $\mathrm{Th}^{232}$ series (Adams, et al, 1958). Uranium is generally found $w$ th thorium in nature in a ratio of about 10 parts of thorlum to one part of uranium. The gamma rays from $\mathrm{U}^{238}$ and $\mathrm{Th}^{232}$ themselves are of such a low energy value as to make direct measurements impractical. Where secular radioactive equilibrium prevails, the abundance of $U^{238}$ or $\mathrm{Th}^{232}$ can be determined by measuring the activity of any daughter in the respective series. This follows from the constant ratios that exist between the concentrations of the various members of a series in an equilibrated sample.

The spectra of uranium and thorium series (Fig. 1) show that the peak caused by lead 212 in the thorium series occurred in a region of fairly constant response in the uranium series and might best fulfill the needs for discrimination of the two series. Furthermore, higher counting rates at this low-energy part of the spectrum make it desirable to work in this part of the spectrum. For a complete discussion on this method of radioactive assay the reader is referred to the work of Kamel, 1962 . 
COASTAL ENGINEERING
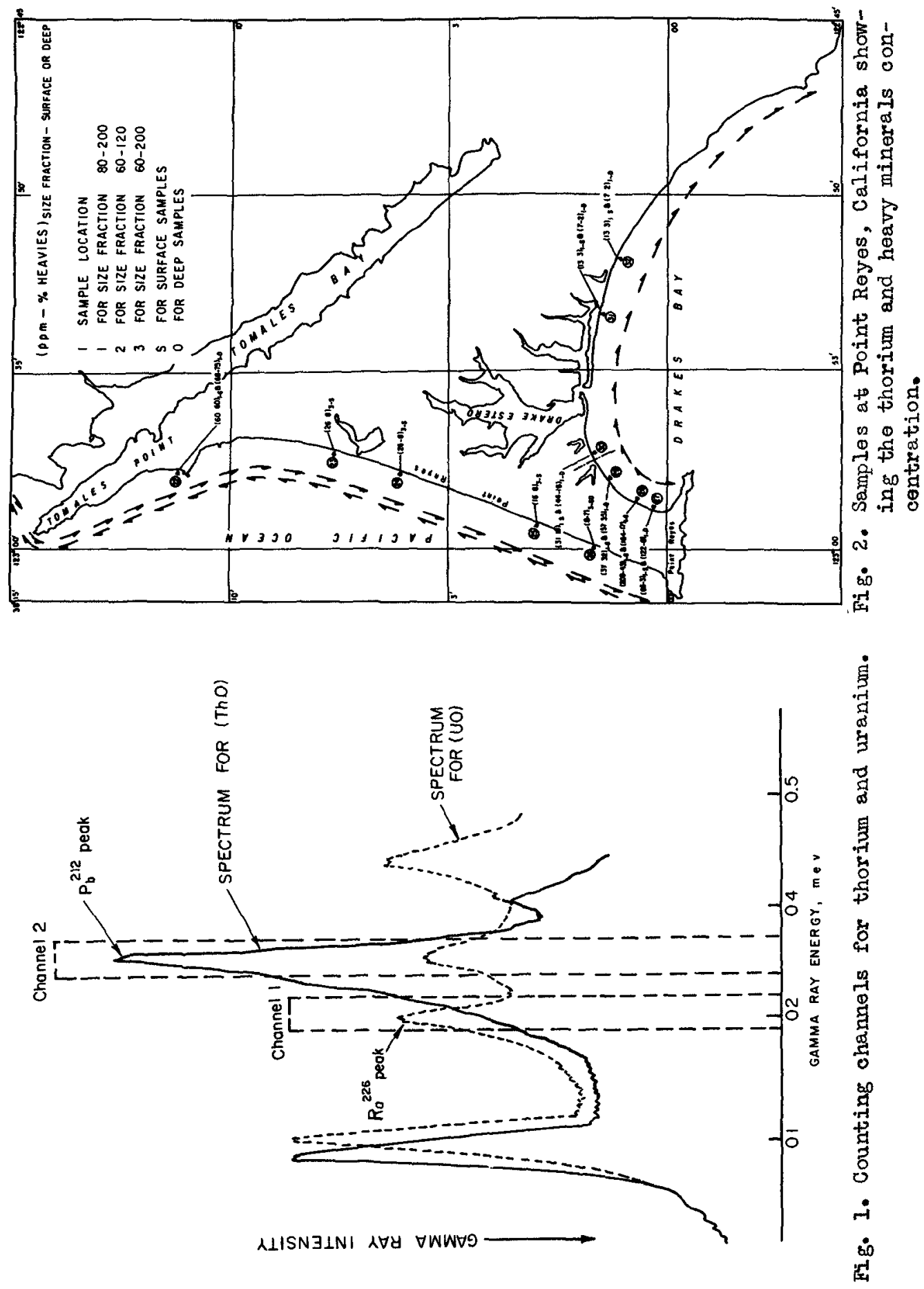


\section{TRACING COASTAL SEDIMENT MOVEMENT BY NATURALLY RADIOACTIVE MINERALS}

\section{INVESTIGATIONAL APPROACH}

It is well known that beach sands are among the best sorted of natural sediments. They are subject to a progressive sorting when transported by longshore currents and to a very effective local sorting by the oscillatory motion of the waves. The contention that sediment transported by longshore currents travels chiefly in suspension is supported by the textural, characteristics of the beach sands. Silt and clay are absent, very fine sand is rare. Any effects of progressive sorting along the shore must, therefore, be explained on the basis of transportation in suspension. These effects may be due to sorting according to grain shape, size, and specific gravity. Progressive sorting according to size, shape, and specific gravity may be due to a progressive decrease in the competency with a lagging behind of the larger, spherical, and heavier particles which move only occasionally during periods of maximum competency. The competency of the longshore current would seem to depend on the ability of the waves to put sediment of a certain grain size in suspension, and then of the ability of the current to move the suspended load. In the present study the choice of the concentrations of both thorite and heavy minerals in parts per million and per cent, respectively, in sand samples collected at mid-tide from different places along the beach, are believed to be two good parameters for the study of the effect of progressive sorting and consequently the determination of the direction of littoral drift along the coast.

A decrease from a source area in the concentration of thorium in $\mathrm{ppm}$ and/or the concentration of the heavy minerals in per cent, should indicate a longshore drift in the direction of decreases of both parameters (Fig. 2).

Local sorting on the other hand, need not be a result of transport in suspension, and its effects must not be confused with those of progressive sorting. To eliminate the effect of local sorting on the sand samples, comparisons between the concentrations of thorium and heavy minerals present in these samples should be made only for a very limited size fraction and not for the whole sample, e.g. a size fraction from 74 to 177 microns.

Since thorium is generally found in the size fraction finer than 125 microns (Hutton, 1951), and since the concentration of heavy minerals is also higher in the fine fraction, it was found that the best size fraction suited for this study is that from 74 to 177 microns.

\section{ANALYSIS OF RESULTS}

Based on the distribution of beach samples and their thorium and heavy mineral concentrations and wave refraction diagrams (Fig. 3) it 
COASTAL ENGINEERING
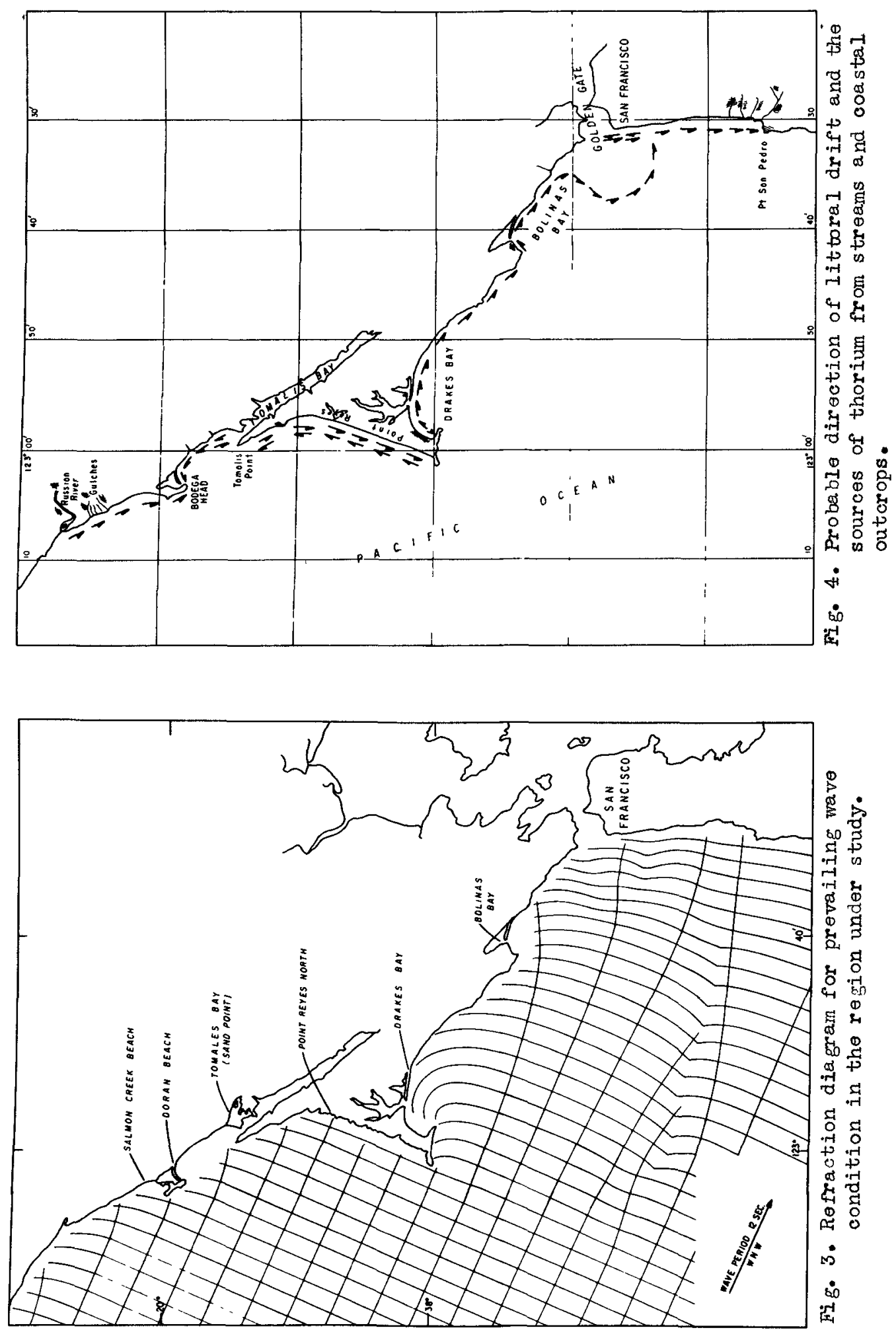


\section{TRACING COASTAL SEDIMENT MOVEMENT BY NATURALLY RADIOACTIVE MINERALS}

is believed that the pattern of sand movement along the California coast from the Russian River mouth to Point San Pedro takes the following form (Fig. 4).

For the part of the coast north of the Russian River mouth though the refraction diagrams indicate a southward drift, the concentrations of both thorium and heavy minerals do not show any consistent or significant decrease in any direction which suggests a possible reversal direction of littoral drift for this part.

South of the Russian River mouth the concentration of both thorium and heavy minerals decreases gradually and consistently in a southward direction. This indicates a southward direction of sand movement which is also confirmed by the wave refraction diagram pattern for this part of the coast.

For Bodega Bay, although a northward direction of drift is indicated by the northward decrease in concentration of both thorium and heavy minerals, the great preponderance of chert and greenstone among the pebbles on Point Reyes Beach indicates that most of the beach material comes from the mainland east of the Point Reyes Peninsula, because no rocks of this character are found on the Peninsula which shows a southward direction of drift. This is also confirmed by the wave refraction diagram pattern.

Wave refraction diagrams drawn for Point Reyes Beach for W.N.W waves with a period of 12 seconds which represents the predominant wave condition in this part, (Fig. 3), show that the direction of wave approach is parallel to the shore. However, waves approaching the shore from the north or south of the W.N.W. direction will result in a southward or northward littoral drift respectively which indicates that sand movement along Point Reyes Beach is subject to reversals in direction.

For Drakes Bay the decrease in both thorium and heavy minerals concentration to the east, wave refraction diagram pattern and the pres ence of porphyry pebbles all indicate an eastward direction of littoral drift.

The eastward decrease in thorium and heavy minerals concentration wave refraction diagram pattern, and the presence of numerous pebbles of Miocene rocks along the sand spit at Bodega Bay, which can only come from the west, all indicate an eastward direction of sand movement along this beach.

The high concentration of both thorium and heavy minerals for the samples taken from the top of the San Francisco Bar and the respective northward and southward decrease of both these concentrations north and south the top of the bar in front of Fleishhacker Zoo at Ocean Beach, suggests very stron the migration of material from the north to the south 


\section{COASTAL ENGINEERING}

along the top of the bar. This material then enters Ocean Beach in front of Fleishhacker Zoo and is diluted in both a northward and southward direction by wave action.

\section{REFERENCES}

1. Adams, J.A., et al, 1958, Determination of thorium and uranium in sedimentary rocks by two independent methods. Geochemica et Cosmochemica Acta. Vol. 13, p. 270-279, 1958.

2. Hutton, C. O., 1951, Uranium, thorite, and thorium monasite from black sand pay streaks, San Mateo County, Calif., Geol. Soc. Amer. Bull. Vol. 62, No. 12, 1518-1519, 1951.

3. Johnson, D. W., 1919, Shore processes and shoreline development, John Wiley \& Sons, New York.

4. Kamel, A. M., 1962, Littoral studies near San Francisco using tracer techniques, B.E.B. Tech. Memo. No. 131, 1962. 